\title{
Globalization and the Future of DEMOCRACY
}

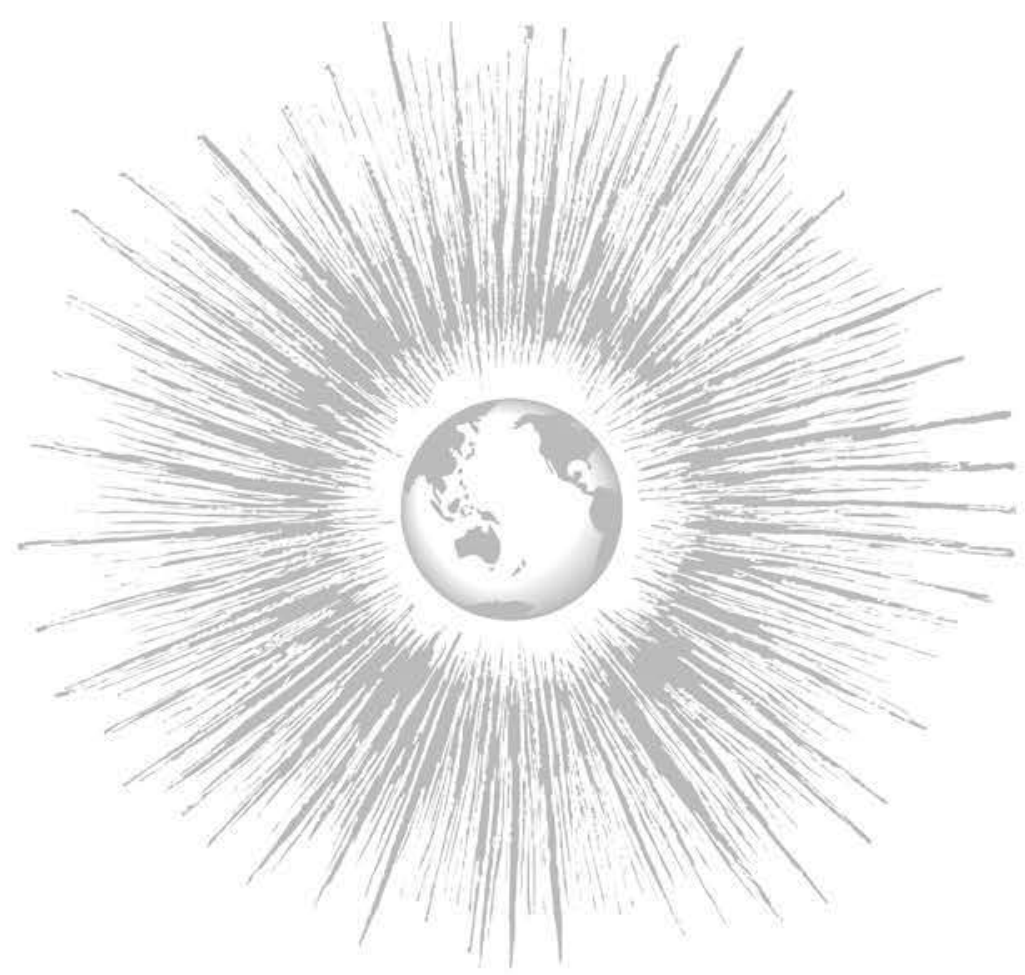

John Markoff

\section{ROUSSEAU GETS IT WRONG}

Writing on the eve of the democratic breakthrough of the late eighteenth century, Jean-Jacques Rousseau gave vivid voice to a critique of the political institutions across the Channel that were admired by so many French reformers of the day. Commenting scornfully on British electoral practice, he observed in 1762 that "The people of England regards itself as free, but it is gravely mistaken. It is free only during the election of Parliament. As soon as they are elected, slavery overtakes it, and it is nothing. The use it makes of the short moments of liberty it enjoys merits losing them."1 Rousseau's contention about the limitations of electoral institutions was in no way superseded by the age of democratic revolution that followed. From the 1790 s to the present, there have been recurrent complaints about the depth of popular involvement in political life, the reality of popular control over powerholders, and the possibility that the existence of some form of institutional channel for participation could blind publics to the inadequacy of that participation. Rousseau's critique has repeatedly reappeared in one form or another and has informed movements for a more genuine democratization.

But as a matter of simple, empirical observation, Rousseau was utterly mistaken about the British political practice he so eloquently despised. For even the occasional contests for a Parliament of uncertain authority in which only a narrowly constituted stratum had the right to vote provided occasions for the political involvement of much larger numbers, often in ways that overflowed the bounds of electoral and even legal practice. Local elites mobilized large numbers for festive parades, distribution of leaflets, and the display of enthusiasm, not to mention the occasional attempt to intimidate the partisans of rival candidates. Not only did a larger target public need to be courted than had the right to vote, but an opportunity for

JOURNAL OF WORLD-SYSTEMS RESEARCH, VOL V, 2, SUMMER 1999, 277-309 hetp: //jwst.ucr.edu/ 
popular forces to bargain with elites was institutionalized. Elections could easily be a time of disturbance as well as celebration, a moment for challenge as well as a ritual of orderliness. ${ }^{2}$ And parliamentary representation created a framework for the petitioning of representatives, including the organizing of petition drives by the representatives themselves. ${ }^{3}$ Only one year after Rousseau's complaint, in fact, the expulsion of John Wilkes from the British Parliament set off a long campaign fought out in the journalistic, judicial, electoral, and parliamentary arenas - and in the streets - that was an early prototype of the modern social movement. ${ }^{4}$

If some of the political institutions of early modern Europe already presented opportunities for popular action, the democratic breakthrough of the late eighteenth century linked together:

+ elites claiming to rule on the basis of popular consent

+ the creation of new formal institutions through which the will of the people was to be shaped, made known, and asserted

+ the proliferation of organizational networks to influence parliaments (in the form of territorially-, occupationally-, or issue-based associations)

- the explosion of journalism, as citizens sought up-to-date information on what was happening on high, those on high sought equally up-to-date information on what was happening down below, and some of those on high sought information on the doings of each other

+ and the flowering of new forms of political struggle for those outside the centers of wealth and power.

Let us glance back before the democratic breakthrough at forms of popular struggle in Europe. It was often very dangerous for people to openly, directly, and collectively challenge the claims upon them of local landowners, urban patriciates, or the agents of governments. Those with little power, therefore, often developed a wide repertoire of methods of self-protection, including concealing of their earnings from tax-, tithe- or rent-collectors, falsifying the ages of their sons when dealing with the recruiting sergeants, and avoiding visible criticism of the powerful.
In some places and times, the rhythms of social life facilitated the forging of collective action. In western Europe before the nineteenth century, for example, market days became occasions for country people not only to come together, but to join with town residents in coercing local authorities to provide flour or bread at affordable prices. Sundays, which brought a rural community together at church, were particularly turbulent since the morning's attention to the word of God could be followed by a decision to mount an immediate attack on some local enemy, most often around issues of food or taxation. A local tavern might be a place where the chiefs of work-gangs of migrant laborers could plan some action on behalf of wages ${ }^{5}$

Most popular collective action took the form of attacks on known, visible, immediate, local targets. At moments of elite division (for example the frequent conflict of local lords and the agents of distant monarchs), or loss of immediate coercive power (for example when the royal army was off campaigning), opportunities for popular assertion were particularly favorable. It is not always easy to distinguish popular forces mobilized by an elite patron in some intra-elite quarrel and popular forces mobilizing themselves to take advantage of some intra-elite quarrel. Nor is it easy to discover the points where popular intervention may have gone beyond favoring one or another elite position more advantageous to those down below and redefined what was at stake by forcing the elites to attend to plebeians' concerns. Assaying the effectiveness of rebellious popular politics, particularly as that effectiveness no doubt varied across space, over time, and from one sort of grievance to another, is a major agenda for social historians. ${ }^{6}$ But my starting point here is noting the epochal shift of the democratic breakthrough of the late eighteenth century*

Several distinguishable yet intertwined processes radically transformed the structures of government and the forms of popular political action. In western Europe, the increasing transfer of power from local arenas to national ones provoked (and was provoked by) new forms of popular politics. Increasingly effective claims by distant authority were matched by a shift away from challenges to local elites - ranging from the multiple forms of hidden resistance to open, collective and violent insurrection - and towards long-term campaigns to influence distant national governments. A full account of the development of new forms of collective action by and 
on behalf of those excluded from the circles of wealth and power would consider:

+ the ways in which changing patterns of earning a living (especially production for distant markets), concentrated urban residence (especially working-class neighborhoods), and concentrated manufacturing created new patterns of solidarity

+ the ways in which new cultural capacities, particularly the development of literacy, did likewise

+ the great variation from place to place in the histories of central political institutions, of literacy and of ways of earning a livelihood.

The very broad result was the intertwined development of new institutions of governance and modern social movements. People on high were bidding for the acquiescence or even the support of those down below; and those down below were creating new ways of influencing the plans of those on high. The institutions of modern democracy and the modern politics of the street developed in tandem. ${ }^{7}$ Parliamentary and electoral processes

+ provided targets for long-term mobilization campaigns

+ created channels for the exertion of influence

- displayed a model for asserting that political action was legitimate to the extent that it was carried on by agents of "the people", with the consent of "the people", or on behalf of "the people," and for conflating these three claims

- diffused political sensitivity to the sheer number of people affiliated with one or another political position on the model of electoral or parliamentary pluralities, thus encouraging organizers to find the means to demonstrate that their positions had large numbers of adherents (including petition drives, mass strikes, and demonstrations).

In these ways the development of democratic institutions encouraged popular mobilizations even against the policies and personnel of the rulers.
(This is the broad picture; much detail including variation in time and space remains to be filled in.)

\section{THE UNEVEN TRAJECTORY OF DEMOCRATIZATION}

The late eighteenth century seems to be a crucial moment in forging the linkages among democratic claims of legitimation, new forms of popular mobilization and new institutions of governance that eventually came to be summed up by the catchall term "democracy." It is symptomatic that the 1780 s appear to be the moment when the word "democrat" entered political discours $e^{8}$ as a term of praise or (probably more frequently) abuse, because people were engaged in attempting to imagine, and realize, new institutions here and now. After North American settlers defeated the greatest maritime power of the age, French revolutionary armies dominated Europe, and Haitian ex-slaves fought off the armies of three empires, the power of democratic claims to legitimation were clear to all, and many states began to make claims that they ruled as the deputies of, with the assent of, or in the interests of "the people" as never before. Even conservative states were coming to do so by the time the French forces went down to defeat. ${ }^{9}$

As states were claiming their rule reposed on popular will, challengers, at intervals, denied such claims with the counterclaim that it was they, the challengers, who spoke for the people, or for some heretofore excluded component. And as elite reformers sought to use democratic legitimation for their own agenda, elite conservatives sought to find some other principle for governance. Out of such struggles, new institutions were created. Democratization advanced in large part in several multicontinental waves. ${ }^{10}$ But democratization was in no way merely the diffusion of some known, fixed model, for in the course of these struggles, new institutions were created that have redefined democracy. Innovation was a multicontinental process, with many points of innovation, although generally not in the world centers of wealth and power. (For example: the first national success for the women's suffrage movement was New Zealand; the uniform adoption of the secret ballot was pioneered in Australia; the writing of national constitutions was launched in the late eighteenth century United States, followed in Europe by Poland; Denmark abolished its slave trade before England did and newly independent Spanish American states were well ahead of the US in abolishing slavery itself-and Haiti was even earlier; many of the states of the new 
United States pioneered in eliminating property qualifications for voting, followed by some of the Swiss cantons; and the very identity of "democrats" was first claimed in the low countries. ${ }^{11}$ ) Democracy in short has never been a finished thing, but has been continually renewed, redefined and reinvented, drawing on political struggles in many places. And in this reinvention, the interaction of social movements and elite powerholders has been crucial.

Although multicontinental in scope and extending across two centuries since the late eighteenth century, democratization has not been a smooth nor a uniform process either temporally or spatially. A look at the Europe of 1815 would have suggested that conservatism as much as radicalism was a legacy of the revolutionary era. In the twentieth century, there have been three major democratizing moments. Struggles about parliamentary powers over ministers and budgets, and over the extension of and equalization of suffrage rights were tremendously accelerated as the First World War went on and on. Although dissenting voices were initially stifled, wartime labor shortages eventually gave increased clout to workers and women (as many women became workers); and post-war fears of revolution led elites to find non-revolutionary routes to meet working-class aspirations. The word "democracy" was used more frequently in public discourse than ever before ${ }^{12}$ and one major power, the United States, even defined the war as about democracy. The western democracies emerged with their political systems more or less intact, despite the vast wartime suffering in some of them. The new states formed on the ruins of empire in central Europe frequently opted for democratic structures, those freed from colonial domination (Iceland and the Irish Republic) also adopted the triumphant model, and other states emerged from revolutionary turmoil, like Mexico and Turkey, to take on democratic elements.

But in the 1920s and 1930s, a wide variety of antidemocratic monarchs, militaries and mass movements subverted or overthrew the new democracies in continental Europe; by the early 1940s the fascists' armies had overrun most of the older ones while antidemocratic regimes were common in Latin America as well (sometimes including fascist elements as in Brazil's "New State"). The defeat of fascism provided the opportunity for a new, and geographically broader, democratizing wave, as western armies remade western Europe and Japan, decolonization in Asia and Africa opened the way for democratic constitutions, and, joining the trend, a number of Latin American states followed suit.

This wave, too, generated powerful counterforces, and during the Cold War antidemocratic currents allied to and supported by one or another side in the U.S.-Soviet struggle challenged hopes for a democratic future. While Russian arms supported communist rule in eastern Europe, the U.S. encouraged the near universal rule of anticommunist generals in South America and both sides supported antidemocratic directions in postcolonial Asia and Africa. So the democratization of the states was not a smooth, uniform process temporally. Nor was it uniform spatially.

As of the early 1970s, democratic institutions tended to be characteristic of countries with high standards of living, and unusual (although not unknown) elsewhere. If about 1970 the core of the world-economy could be said to have largely (in some places recently) democratized, in the next multicontinental wave the locus of the democratizing transformation was, approximately, the semiperiphery ${ }_{+}^{13}$ In the 1970 s the military overthrow of Portugal's long-standing authoritarian regime launched the most recent wave of democratization, which has by now embraced other southern European states, most of Latin America, eastern Europe, several Asian cases (South Korea, the Philippines, Taiwan), and South Africa, and was still continuing into the 1990s with struggles for democratization in Kenya, Nigeria, Burma, Hong Kong, Indonesia and elsewhere. In geographic range this has been the most extensive wave of democratization thus fat;

On the eve of a new millennium, more people in more countries than ever before in human history had a voice in the selection of the incumbents of political office in the states of which they are citizens. Some observers have been so carried away by the sudden surge as to make millenarian pronouncements to the effect that history is now over and the democratization of the remaining states will be simply anticlimactic. ${ }^{14}$

If we try to understand the current moment in relation to democracy's history, however, it seems to me that this is not an occasion in which democrats should be complacently celebratory, but concerned, perhaps even alarmed. Democracy's future is deeply threatened in several ways. Let me sum up the past two hundred years of democratic history. The intertwined histories of democratic legitimations, social movement activism and institutional changes generated, in some of the world's states, a significant 
democratization of the institutions of government. Despite antidemocratic countertrends,,$^{15}$ the long run direction of change in some of the states was a democratization of state power. What I shall be suggesting about the current moment is three-fold.

First, there are in fact very significant countercurrents that threaten, as in the past, the democratization of the states.

Second, the current moment is one in which it is becoming evident that the democratization of (some of) the states is not remotely enough to assure a more democratic world.

And third, the mechanisms that were so important in achieving the (very imperfect) democratization of (some of) the states are very unlikely to be capable of achieving the democratization of the emerging new structures of power.

\section{THE CHALLENGES OF GLOBALIZATION}

The question of new structures of power is crucial. The interplay of democratizing institutions, democratic legitimations of power and social movements was born out of an epochal redeployment of power from local to national arenas. The end of the twentieth century may be another such epochal moment of redeployment of power, from national states to a variety of trans-statal structures, which are probably still only in embryonic form. This much-discussed globalization presents some significant challenges to the democratization of the states, some of which I shall touch on here. But these transnational processes are raising in a very stark way an issue beyond the democratization of the states. For we must recognize that the entire modern history of democratization has been, and continues to be, precisely the democratization of some, but not other, states. Democratization has given some people, but not others, some measure of control over those on high. Globalization is not only a challenge to the democratization of the states. It raises the issue of whether the democratization of the states is even going to continue to be meaningful in a world of transnational connection. What will be at stake, in the twenty-first century's history of democracy, if there be any to reflect on at the next century's end, will be the question of what a more democratic world might look like. I will first examine the threats to the democratization thus far achieved of the national states, and then turn to the limitations of that achievement. I shall consider this first group of issues under four broad heads: the meaningfulness of electoral accountability to citizens; the nature of citizen ship; the reinvigoration of exclusionary politics; and, last but hardly least, the continued effectiveness of social movements as a force for democratization. These issues are all intertwined, but I shall not attempt to map out all the interconnections here.

Although distant places have often had significant economic linkages, the volume and diversity of these linkages has enormously expanded as capital investments, goods and services, and (although to a significantly lesser extent) labor have become mobile as never before. Giant corporate actors and otherwise atomized individuals alike can enter into near instantaneous contact with distant interlocutors through fax and e-mail. Governments, partly as a consequence, have been losing their capacity to control the economic and cultural life of the territories vulnerable to their authority, but additionally now often seem eager to shed some of their traditional responsibilities in the name of the allegedly superior efficiencies of the globalizing marketplace.

And now we enter a realm of claims and counterclaims about this web of transnational connection whose students have made the most varied arguments ${ }^{16}$ For some, the sheer quantity of global financial transactions, or the flows of immigrants (legal and otherwise), or the economic clout of transnational criminal enterprises, or the geographic reach of pop music amount to an overwhelming case that we are entering an utterly novel era, in which the states are less weighty players, utterly unable to control these diverse flows. A very different response is suggested by the world-system argument to the effect that the capitalist world-system has always involved separate states enmeshed in a transnational economy subject to their influence to some extent but securely beyond their effective control. Others argue that use of the grand term "globalization" to include transborder connections that might be merely dyadic or that might be regionally circumscribed is deeply misleading* Others yet again contend that some of those misleading claims are deliberately misleading, are ideological defenses for attacking worker rights in the name of the tough measures that are allegedly necessary in the face of the inevitably global marketplace (claims that run much stronger in the United States than in most of Europe). And still others argue that the central change is an increased awareness of crossborder processes, some of which are not in themselves of especially recent vintage; an important vari- 
ant of this last contention goes on to point out that this newfangled global awareness can itself be the motor of further change. So some see epochal change and others write of "the globalization hoax" or even "globaloney"; some in France speak of "globalitarianism",

Distinguishing trends in the web of transnational connection from changes that are cyclical in character; distinguishing both trends and cycles from transnational phenomena of long-standing that have been mistakenly thought to be new; distinguishing increasing transnational flows of people, goods, and ideas from increasing awareness of such flows; and distinguishing statements that are true of one or several locations from those that are true of the world as a whole constitute a very large but urgent research agenda. I believe the available evidence suggests that there are both frequently exaggerated claims of novelty that are simply mistaken and purposeful attacks on social programs in the name of the global marketplace-both of which are important to correct and challenge. Nonetheless, I also believe the available evidence to indicate that there are both cycles and trends ${ }^{17}$ whose character may be clarified as systematic research catches up to anecdote and hype. Among those trends is a proliferation of transnational mechanisms for economic decision-making ${ }^{18}$

The impulse to transnational structures for decision-making is multiply motivated, rooted in various forms of crossborder connection that generate threats from which even powerful elites may be unable to protect themselves without new structures of governing. These include: the invention and subsequent diffusion of nuclear weapons and globe-circling missiles; the more insidious long-term challenge of potential global environmental devastation; and the possibly ruinous consequences of uncontrolled global economic markets. These have all impelled the powerful to begin to create new mechanisms of crossborder coordination.

\section{THE MEANINGFULNESS OF ELECTORAL ACCOUNTABILITY TO CITIZENS}

In this emerging world of transnational connection, the abilities of national governments to manage many important things are diminishing ${ }^{19}$ Control over flows of capital is proving especially elusive, but the movement of goods and even of the relatively less mobile individual workers have proven hard to control as well, Effective decision-making power over parts of the transnationalized economies is becoming established elsewhere than the states, and in several forms:

There are formally constituted trans-statal quasi-governments of which the European Union is the most powerful within its formal jurisdiction and the United Nations the geographically broadest in its scope. The European Union's executive agencies have an enormous capacity to issue a myriad of binding regulations affecting business and consumer interests, but the EU is also involved in redefinition of welfare rights, environmental concerns, educational practice and even human rights issues. For its part, the United Nations' recent propensity to dispatch various combinations of relief workers and armed soldiers in the name of human rights to various places defined as "failed states" (as in Somalia, Zaire or Bosnia-Herzegovina) suggests a new tendency of trans-statal organizations to regard national "sovereignty" as less sacrosanct than heretofore. As the post-World War Two norm that all should live in sovereign states came to approximate fruition with decolonization and the breakup of Soviet Europe, sovereignty itself became blurrier.

There are also formally constituted agreements for regulating the levels and nature of economic integration without other quasi-governmental trappings of which we might take the North American Free Trade Agreement (NAFTA) among Canada, the United States and Mexico or South America's Mercosur as models. Agreements of this sort have the potential to significantly constrain not only economic policy, narrowly conceived, in the signatory states, but a whole range of other concerns, including environmental and even human rights issues. It might for example be claimed that such and such a conservation measure violates the free-market provisions of some agreement. It seems merely a matter of time before some powerful economic interest launches a lawsuit claiming that some government's public education system constitutes an improper subsidy of economic rivals.

And then there are agreements among financial interests to make major decisions about the geography of capital flows of which the International Monetary Fund and the World Bank are by far the most consequential. Successful agreements between a state and those organizations are taken by other financial interests as the transnational equivalent of a good credit rating. $\mathrm{A}$ full survey would include the various forms of multinational corporation, the subcontracting corporate relationships centered in Japan, and the 
Asian business networks linked through kinship ties, as well as the transnational networks that move falsely labeled commodities ranging from clothing with fake labels to pirated CDs and the vast trade in illicit psychoactive substances. Among such hidden structures of crossborder negotiation, perhaps we ought not to omit some of the activity of governments themselves, in particular some of the secretive meetings among finance ministers of the major industrial countries, currently constituted as the G-8.

The simple, but very important consequence: at the historical moment when more citizens of more states than ever before in human history have been acquiring some control over the incumbents in office of the national states, the capacity of those incumbents to function as autonomous national policymakers has been seriously eroding. Few governments in the world today risk a serious confrontation with the economic policies dear to the IMF and World Bank ${ }^{20}$, for example ${ }^{21}$. No government seems able to prevent its police forces from supplementing their salaries from the treasuries of transnational criminal enterprises. The relationship between the wishes of elected politicians and the rulemakers of the European Union is exceedingly complex. Crossborder infusions of money now seem a feature of U.S. presidential election campaigns, suggesting that the use of foreign funds to influence elections would no longer be exclusively a tool of US-based interests operating abroad but could run in the other direction as well. ${ }^{22} \mathrm{We}$ could sum this up as a diminution of national sovereignty.

In short, states are weaker in the global marketplace. This particular challenge to democracy is very profound: publics, to an unprecedented extent - if far from everywhere - can choose incumbents but it hardly follows from that fact that they thereby can choose policy, especially on central matters of economic life.

\section{WITHDRAWAL OF STATES FROM COMMITMENTS TO WELFARE}

An important aspect of these diminished state capacities is the degree to which states are doing it to themselves ${ }^{23}$ Students of contemporary western European polities, for example, speak of a hollowing-out of the state, as all sorts of functions pass upwards to transnational bodies (like the European Union), downwards to reinvigorated local or regional organs of government, and outwards in the form of privatization (which may be accomplished via deregulation, sale of assets, or the replacement of bureaucratically supervised public services by contracting out to private agencies). In the United States in recent years we have seen the federal government turning over much of its poor relief to the states and some of its vast population of imprisoned persons (by far the largest such population in the world) to private prisonproviders. In other parts of the world, we have seen the collapse of European communist regimes, the embrace of the market by their Asian counterparts, and a general retreat from commitments to state-led developmentalism in many poorer countries. Most Western European states are moving, with varying misgivings, to give up the economic leverage afforded by control over their own currency in favor of the common Euro.

So there is an ideological dimension to restricting the sphere of state action, in which even holders of state power are participating. The belief in the superiority of "the market" over "the state" has many components ranging from ethical claims about human freedom to technical claims about efficiency, so there are many arguments that devalue central political institutions in favor of "the private sector", the "local community", "the family","the individual", or "the free market." Champions of such positions maintain that the agents of states have been responsible for many evils, including hindering the wealth-generating capacities of less regulated economic enterprises. In this view, those who saw states as agents for either the generation of wealth or its more just redistribution, were, at best, well-meaning but mistaken. The untrammeled marketplace will augment aggregate wealth and the interplay of market forces will on its own, in the fullness of time, redistribute that wealth and relieve the crushing poverty in which many live. Redistributionist state actions are folly, and accumulationist state actions even worse. Not to worry - a rising tide raises all boats.

In fact, the empirical evidence suggests that on a world scale this particular rising tide merely raises all yachts. In the recent period of state retreat, and concomitant acceptance of the global market as the central social institution to which all other institutions need accommodate themselves, the income gap between the poorest and richest has been growing apace ${ }^{24}$

Of course, there is nothing especially new in some people being much poorer than other people. What is striking about the current moment, however, is how issues of poverty have become marginal in political debates in some of the richer countries. In the United States and in Great Britain, for example, the major parties vie with each other for the votes and support of 
everyone but the poot. ${ }^{25}$ And should recent trends in income distribution, globally, continue - to be sure this is a speculative matter about which much controversy swirls ${ }^{26}$ - it is not hard to wonder if poorer people in democratic countries will indefinitely continue to assent to a political system in which the major parties compete in ignoring them. In the new economic order lifetime careers may be giving way to part-time, temporary jobs. Enhanced freedom from state regulation for owners of capital means downsizing, flexible specialization, outsourcing, capital mobility across interstate frontiers, and rapid technological change that threaten economic insecurity for many. Even middle-class homes are threatened with economic insecurity as a permanent state of affairs. It is hard to see why political challenges to the constitutional order will not eventually be heard.

In this connection, let us consider the recent, widespread reversals of social welfare policies. Many students of politics since World War Two simply assumed an inevitable connection of expanded rights of democratic participation and expanded social rights. ${ }^{27}$ If all adults have the vote, so the argument went, of course the large numbers of people who feel economically threatened by potential medical costs, old age, expensive education for their children, and so forth, would support programs of social provision. Such programs in turn would attach large numbers of people to the current constitutional order. So democratization would promote social provision and social provision in turn would assure large majorities favoring democracy. But the first half of this relationship has suddenly and rapidly eroded - raising important questions about the second half.

Let us briefly consider the unexpected withdrawal of the wealthier democratic states from social provision. Relevant aspects of the current climate, some already discussed, include:

- widespread embrace of notions of priority for the market over other human institutions

- the weakening of labor as a political force

- pressures to reduce government expenditures coming from transnational financial networks

+ expedient concern for competitiveness in the global marketplace
+ the invocation of the global marketplace by the powerful in order to convince democratic publics to acquiesce in an increase of profits at the expense of labor.

\section{LATE TWENTIETH CENTURY EXCLUSIONARY POLITICS}

Part of what gives anti-welfare positions their special force today is a fragmentation of political identities. To the extent that poorer people are identifiable as ethnically distinctive, including an identity as recent immigrants, some political parties are able to denounce welfare as taking from "us" to give to "them." With millions of North African Moslems in France, Turks in Germany, and Albanians and Africans moving to Italy, the mobilization of xenophobic sentiment is readily linkable to an attack on welfare. When Surinamese or Indonesians show up on Dutch welfare roles, the Dutch rethink their generous unemployment insurance. Moreover, the weakening of labor in the transnational marketplace reduces the likelihood that a collective identity as workers will effectively override this fragmentation. The shift among a portion of France's workers from voting for the Communists to voting for the anti-immigrant National Front is an important sign of the power of anti-immigrant politics in an age of globalized economics.

In the absence of policies directed at their inclusion, in the absence of notions of minimal acceptable standards of life guaranteed by a national community, will large numbers of poorer people feel materially or symbolically excluded from national life and simply opt out of support for a democratic practice that no longer aspires at both their inclusion and material advance? Such a possibility may be more profoundly corrosive of democracy than the direct exclusionary notions of xenophobic parties.

But xenophobic politics is by no means insignificant. Patterns of economic, political and cultural transformation have made political conflict over national identities dramatically salient, with the fragmentation of the Soviet Union, Yugoslavia and Czechoslovakia and the unification of Germany; with the murderous violence in ex-Yugoslavia and some of the fragments of the ex-Soviet Union, and massacres in Rwanda; with the cycles of violence and counterviolence surrounding the rights of groups in Ethiopia, Sri Lanka, India, Turkey, and Northern Ireland; with the increasing significance of political conflict over immigration policy in the wealthier countries, including Germany, France, Italy and the United States; and with continu- 
ing challenges to the present national state in Canada and Belgium ${ }_{+}^{28} \mathrm{Cur}$ rent social transformations assure that conflicts defined by the participants in ethnic terms will continue to be a highly significant part of political life in many countries. Such conflicts in themselves are hardly unprecedented; what is to the point in the present context is the challenge conflicts structured around such identities pose for democracy*

Capitalism continues to ensure change in which productive processes and which places on the globe prosper, which scrape by, and which are impoverished. The radical and rapid shifts in the location of technological innovation mean that some economies boom while others decline (and some may do both in rapid succession). While some firms grow and others shrink, new university graduates of programs geared to last year's job market often find themselves un- or under-employed. As contemporary means of computer-related communication permit enormous flexibility, the proportion of young people who can look ahead to permanent careers within bureaucratized firms whose bureaucratic hierarchy defines career possibilities, may very well shrink as firms downsize, outsource, shift to part time workers, or fail altogether in competition with firms in other countries. Economic insecurity now seems likely to be a significant element in many a middle class professional life for the foreseeable future in many a country.

Insecurities make the appeal of security great, and some will urge the restoration of the communal culture of the past, often a fictive past, as a shield against the individualizing, isolating, and anxiety-generating forces of modern economies. This past can easily be defined in part in ethnonational terms: foreign investors are destroying the national patrimony and the national community, new immigrant workers take our jobs and subvert our culture, established minorities were never real participants in the national essence and need to be subdued or expelled. The increased role of denationalized technocrats in positions of visible political power ${ }^{29}$, and the openness of national economies to the transnational economy that those technocrats tend to promote, help sustain a communally oriented embrace of (possibly imaginary) traditions. Religious fundamentalisms, xenophobic political parties and ethnic violence are all energized. In the wealthier countries today we see as a consequence some interesting divisions among those who identify with the political right, as some embrace reviving supposed communal traditions and the moral virtues under challenge in an individualistic age, while others champion the global capitalist marketplace and proclaim the individual will to be the sole repository of moral authority.

This is an economy in which the dictum that capital has no country is as close to realization as it has ever been. This is an economy in which wealthier countries have large numbers of immigrants, permanent, semi-permanent and temporary, and in various degrees of legality; in which transnational political institutions deploy armed force; and in which cultural hybridity is as close as the omnipresent TV. Such an economy generates political movements of the threatened, and countermovements of those threatened by these movements. Some of these movements and countermovements focus on the incursions of transnational capital and the semi-treasonous actions of national governments that fail to protect the national essence. Others address the cultural challenge posed by the sacralization of the market. If market-worshipping governments no longer subsidize the costs of paper and printing and do not provide subsidies for writers and publishing houses, for example, what intellectuals take to be respectable work may vanish from the bookstores as no longer commercially viable, while cheap translations of (and local mimicry of) foreign romances, pornography, tales of UFO encounters and pop psychology rapidly proliferate. ${ }^{30}$ While some champion the freedom of the free market, others deplore what are held to be its cultural consequences. ${ }^{31}$ Foreign workers are a particularly common target in the wealthy countries. Some of the claims being made about the unprecedented character of late twentieth century transnational labor mobility need to be toned down somewhat in light of late nineteenth and early twentieth century labor mobility (with few legal restrictions). Nonetheless, at a moment of heightened anxiety and enthusiasm over globalization, the worker from elsewhere is often a more immediate target for resentments than the distant decisions of banking consortia or those in charge of TV programming.

For at least three reasons, many students of democracy regard such conflicts as very difficult to address within the confines of democratic procedures. All three deserve extended discussion; here I only comment briefly on each.

First of all, strongly held identities may challenge the very existence of a national state. To those for whom such identities are a more significant matter then the procedures followed by the alien and inherently oppressive state under which they feel they live, it may be a matter of indifference how 
that state is governed: indeed to the extent that democracy seems to secure the allegiance of citizens, including citizens of the nationality for which the nationalists claim to speak, democracy itself may be held to be a target to be destroyed if possible. The actions of some parts of the Basque separatist movement in the post-Franco period have been in this vein.

Second, it is often suggested that conflicts framed in terms of collective identities are far less subject to negotiated compromises than conflicts framed in class terms. ${ }^{32}$ Where the conflict of labor and capital dominates, one can imagine all sorts of compromises* at the crudest level, labor accepts certain levels of profit and capital accepts certain levels of wages. Conflicts over the claims of minorities to distinct educational systems, distinct public use of language, and public displays of religious affiliation often do not have any very obvious intermediary position.

Third, democratic protections for free speech and free association permit political mobilization around ethnocultural questions that may sometimes be successfully stifled under authoritarian political systems. A transition toward democracy may also be a transition toward open expression of inflammatory positions. The murderous violence in ex-Yugoslavia in significant part derives from the capacities of political elites in Serbia and Croatia to mobilize nationalist appeals within a partially democratizing context. But it is not merely a matter of the limited character of the democratization. The violent intimidation of the Czech Republic's gypsy population in the 1990s is happening in a state whose democratic features are far more developed than those of ex-Yugoslavia. In ex-Communist Europe, indeed, the expression of ethnically defined hostilities is part and parcel of the experience of recent liberation from coercive states defining the limits of acceptable public discourse. Anti-Russian speech (and legislation) in Latvia and Estonia, anti-Gypsy violence in the Czech Republic, Hungary and Romania, and anti-Jewish speech (without legislation) in a near Judenrein Poland are part and parcel of those countries' democratizations.

\section{THE FUTURE OF SOCIAL MOVEMENTS AS DEMOCRATIZING FORCES ${ }^{33}$}

Let me turn now to the continued effectiveness of social movements as a force for democratization. Recall that as power passed from local lords and local officials in Europe to central authority, people engaged in conflicts began to develop new techniques to press that new authority to act on their behalf. The emerging movements became a critical element in the democratization of the states and democratization encouraged further movements. Indeed, the movements became an element that shaped the very contours of state power, as those states took on vastly expanded welfare and police activity in part in response to pressure and threat from below.

We appear to stand at another such epochal moment of redeployment of power-away from national states and toward transnational actors. It is far from obvious that social movements as we have come to know them over the past two centuries will be able to operate with the same effectiveness in relation to transnational structures of power as they have in relation to national ones. Of all the issues I am discussing here, the most serious in my view is the possibility that there may be no forms of social action for the effective democratization of power. But we need to review what is happening to movements in the present in order to speculate about the future.

The attention that scholars of social movements have been devoting to the transnational aspects of movements has been expanding so rapidly that virtually anything one says based upon current research might have to be rethought in the future (and the forms of political action may themselves be in flux). Nonetheless, I believe this recent research ${ }^{34}$ thus far suggests the following three statements:

Throughout the entire modern history of social movements, notions of strategy and tactics, models of organizational forms, general notions of social justice, and participants in social movement activism have frequently crossed national frontiers.

In the past few decades, a wide variety of transnationally organized activists have made intermittently effective use of international organizations, NGO resources, and the governments of some national states to address issues in other national states. For the most part, the activities of such transnational activist networks do not include the collective, public, mass mobilizations that some see as among the defining hallmarks of social movements.

Although the institutions of transnational power have been targets of mass mobilizations (as well as of the lobbying campaigns of transnational advocacy networks), for the most part social movement activism has contin- 
ued to address national states, although sometimes with an eye on having that state take some action on some transborder matter.

There are several distinct levels on which social movements might respond to the shift in power from national states to transnational structures. We might look for analyses by activists that recognize the transnational character of issues. We might look for the development of transnational organizations. We might look for the deployment of tactics that address transnational sources of power. Instances of all of these are not hard to find. People in the environmental movement have often spoken of the global context of environmental issues, have held international conferences to exchange ideas among themselves and sometimes have acted across national frontiers. The human rights movement also has a strong tendency to organize across state boundaries. The very notion that we have rights as human beings, not only as citizens, and that as fellow human beings we need to support each other against abusive governments, is in itself a challenge to notions of national sovereignty. Women's rights activists have made some effective use of international organizations. Popular protest on several continents has been mobilized around actions of the IMF and World Bank.

Nonetheless, it seems fair to say that, thus far, the principle way social movements have acted in the transnational arena is to deploy their own traditional techniques of political action. People moved by some transnational issue have been, on the whole, inclined to challenge their own national governments to take some position in the transnational arena ${ }^{35}$ Environmentalists, for example, demand that their governments sign some treaty among governments protecting the sea or the air; human rights groups demand that their governments stop supporting other governments that violate human rights. And when it comes to economic policy, challenging one's own government is overwhelmingly the main arena of action of today's movements. Margaret Keck and Kathryn Sikkink have shown a rapid increase in the number of organizations engaging in transnational political activism (by their figures, from 102 in 1953 to 569 in 1993) but they have persuasively shown that these organizations are, for the most part, not engaged in mobilizing transnational collective action ${ }^{36}$

Not only do social movements still largely move in their own national arenas, but the gains they have made over the past two hundred years have largely been at the level of the national state. The labor movement, for example, so important in the history of democratization, has largely achieved its successes through national labor legislation. But with the rapid transnational deployment of power, the capacity of labor's traditional modes of action and organization to advance the interests of workers has declined with remarkable rapidity in the traditional industrial heartlands. If owners of capital can easily move their investments to another country, it is extraordinarily difficult for the labor movement to take effective countermeasures. Its traditional means of engaging in conflict, which we may summarize as striking, demonstrating and voting have all been reduced in effectiveness. Strikes are a riskier business when capital is so mobile, and mounting demonstrations as well as effective use of the ballot have been weakened by the fragmentation of a worker identity. The environmental movement has the proud slogan, "Think globally, act locally." But for many issues there may be no effective local actions.

This does not mean that social movements have no effectiveness at all in relation to transnational power. Even acting locally, the environmental movement has significant achievements. European farmers or truckers demanding that their governments take particular actions within the governing structures of the European Union have sometimes had considerable impact. And human rights protesters challenging their own governments to withdraw support from South Africa in the 1970s and 1980s helped bring about an international climate that encouraged the dramatic abandonment of that country's racially organized governing structure. Jackie Smith's quantitative inventory of the growth of "transnational social movement organizations" between 1973 and 1993 finds that more than half of such organizations at that latter date can be grouped under three broad rubrics: "human rights", "environment" and "women's rights", ${ }^{37}$ which suggests that an exclusive focus on the labor movement may miss much of the transnationally coordinated collective action at the turn of the new century (and some labor issues may be pursued under these other labels). The forms of pressure so finely anatomized by Keck and Sikkink have had their successes, too. 38 For the most part, however, it does seem that social movements are not acting directly on the new centers of power and that there is (as yet?) only limited movement in that direction. When we consider the webs of transnational finance, the element of democratic accountability not only vanishes completely ${ }^{39}$, but the points of possible leverage for democratization are far from obvious. 
Recall that democratizing states fostered social movements by legitimating collective action in the name of the people; by building institutions like parliaments, executive agencies and judicial systems that collective action could target; and by providing channels for lawful collective action in periodic elections and legal processes that could galvanize other forms of collective action, some in violation of law. Although some elements of the institutions of transnational governance are analogous in some ways - the European Union has its weak parliament in Strasbourg, for example-for the most part there is a lack of such visible centers of power, a lack of obvious occasions around which to mobilize, and a lack of the sort of common democratic discourse that by the early nineteenth-century in Britain, for example, came to enfold both the politics of the palace and the politics of the street in the shared claim of popular representation.

As monarchical, aristocratic and corporate powers democratized, the new states aspired to the ceremonial majesty and legitimacy claims of the previous monarchical order, but now it was democratic majesty that was proclaimed. Thus the great public buildings of Washington, D.C., with Congress apart from the White House, beautifully, simply and powerfully gave visible form to the notion of separation of powers. And elections are a dramatic ceremonial reminder of democratic legitimation. The emerging structures of transnational decision-making, however, do not have such features, and much of their activity is even hidden. The inner processes of the World Bank and IMF, to take two conspicuously significant examples, are hardly publicized and positions taken by many national representatives to those organizations are not even made publicly available. ${ }^{40}$ Rather than legitimacy, it is invisibility that is sought. How such power might be democratized is the challenge of the twenty-first century.

\section{BEYOND THE NATIONAL STATES}

So the democratization of the states, geographically extensive as it is, can hardly be regarded as secure. But let us take a geographically yet more extensive view. Although successive waves of state democratizations have left a legacy of expanded accountability of governments to citizens in increasing numbers of states, very large numbers of the residents of the planet have not benefited. Democracy has always been deeply exclusionary.
As late eighteenth-century legislators, at the moment of revolutionary democratic breakthrough, planned their new political systems, the question of to whom, precisely, governments were to be responsible came to the fore, and democratizing states adopted a distinction between citizens with and citizens without voting rights. Women, those with little property, children and domestic servants were commonly excluded and at various times and places since some have been excluded for ethnic criteria, criminality, mental deficiencies, illiteracy and membership in the clergy or military. The common expression "universal suffrage" has been and continues to be one of the most obfuscating terms in the vocabulary of modern political life. Tocqueville, for example, set himself the task of explaining the remarkable universal suffrage of the United States, at a moment when women could vote nowhere and free blacks in the north, even when not legally barred from voting, confronted threats of violence should they attempt to do so. ${ }^{41}$

In the late twentieth-century democratizing waves, countries claiming the mantle of democracy have something that might properly be called near-universal adult suffrage, with children constituting the largest category of excluded citizens. What stands most starkly revealed, therefore, is the distinction of citizen/noncitizen. To the extent that we see democratization as a series of successful attempts by social movements to secure rights, we also see that those rights were largely secured for citizens of particular national states and largely secured within those states. Toward the beginning of the era of modern democracy the very title of the revolutionary French Declaration of the Rights of Man and Citizen encapsulated a very important ambiguity: did one have rights because one was a human being, or because one was a French citizen? To the extent that rights are claims that are empty unless they constitute an obligation on some party with the resources to actually meet that claim, for the most part what rights a person had were obligatory only for the state of which that person was a citizen. In addition, interstate treaties might sometimes grant reciprocal rights of various sorts, and multilateral interstate documents might speak of other, "universal," rights, which courts in some states might sometimes take to constitute state obligations. But generally speaking, rights are connected to citizenship and enforceable in relation to the state of which one is a citizen. This includes, very importantly, political rights. 
By the late twentieth century, pervasive notions of democratic legitimation within states and multilateral human rights treaties among states seem to be creating new challenges for some legal systems confronting long-term resident non-citizens, asylum-seekers of various sorts, and transnationally mobile workers. Some see the emergence of new kinds of rights claims not anchored in national citizenship. ${ }^{42}$ So issues of inclusion/exclusion along the citizen/noncitizen fault line are highly salient. In addition we have, following Keck and Sikkink, pointed to the rapid proliferation of organized activism (but not taking the form of social movements) in which participants attempt to influence the policies of states not their own. That such advocacy networks have some significant successes still doesn't amount to any routinized rights of participation.

Despite such developments, we may say that an important aspect of the history of modern democracy has been that much of the world's population has never had available to them institutional mechanisms for holding the powerful of the world responsible for their actions. For the most part, the more securely established democratizations up to the current wave meant that citizens of the wealthier and more powerful states had some control over the incumbents in office of their states. Very much to the point are Immanuel Wallerstein's ${ }^{43}$ observations to the effect that the democratization of some of the states since the late eighteenth century to a large degree incorporated the working class of the wealthier countries into the system of global inequality on relatively favorable terms. With some economic security in the form of social rights; some say in public affairs in the form of political rights, as exemplified by the suffrage; and with rights of association, speech, petition and so forth that undergird the capacity to engage in social movement activism, and the consequent dignity that goes with such empowerment, large numbers of people in a small part of the world came to participate in what has still been profoundly exclusionary democracy. The exclusionary character of such democracy is in plain sight, yet unnoticed as long as we only cast our gaze on the governance of the states, separately.

There was no necessary incompatibility at all between the democratization of the core states of the world-economy in the nineteenth century and the extension of colonial rule by those same states. Democratizing movements might come to secure rights at home, while state violence was projected outward onto other continents ${ }_{*}{ }^{44}$ In the nineteenth century, work- ers in the centers of world economic and military power obtained rights at home, but also manufactured the guns and warships, built and staffed the communications networks and enlisted in (or were conscripted into) the armies that fostered and maintained colonial rule over subject peoples. ${ }_{*}{ }^{45}$

Perhaps even a stronger statement is warranted. It may be that the democratization of the core of the world-economy owes a great deal to the control of sufficient resources to pay for the extension of rights, while that extension helped secure democratic popular assent for global domination. The correlation of high national income and democratic political practice is one of the best-attested regularities in the literature on democratization ${ }^{46}$ (although many have attempted to explain this relationship differently). This important role of the core in the world history of democracy intersects the social struggles within, and among, the states out of which the actual institutions of democracy emerged in temporally clustered bursts of increasing geographic range. But we must bear in mind that this has never been a process strictly confined to the core. In the period, for example, when conservative forces dominated Europe that stretched from the Congress of Vienna until the tumultuous early 1830s, the world centers of democratization were in the western hemisphere. And, as indicated above, not only have major institutional innovations been pioneered in the semiperiphery, but many of the instances of democratization in the late twentieth century wave have also been semiperipheral.

The uneven democratization of the states at the dawn of a new century confronts new challenges. The recent combination of extended - but hardly "global" - geographic range and potential trivialization that together characterize the most recent wave of democratizations raises anew questions of political power beyond the national states. The density of economic and cultural interconnection across national frontiers now threatens to trivialize the democratization of those states that have achieved significant democratization, raising the question of whether there is a meaningful future for the democracy of the states that does not address democracy beyond the states. The democracy of the states has always been a profoundly unfinished thing, as movements have utilized democratic legitimations and institutions to push further democratization. The democratization of the world beyond the states has yet to begin. 


\section{CONCLUSION}

The present moment in the history of democracy is not, therefore, an occasion for triumphal celebration but for concern. To summarize: the remarkable and radical geographic extension of democratic practices coincides with a number of serious threats. The leaching of power out of the national states, in part towards a variety of transnational institutions, raises the specter of a trivialization of the very real democratization of the states. The mobility of capital and workers on a transnational scale reenergizes political conflicts around inclusion and exclusion. And last, but hardly least, the future of social movements, a major source of the democratization of the states for the past two hundred years, is in serious doubt, at least as far as their capacity to democratize the emerging global order is concerned. In the past, as labor actions threatened, investors have relocated outward, often recreating the labor conflicts they had fled ${ }^{47}$ But as the focus of power shifts upward beyond the bounds of the state, any state, it is not obvious that labor movements, or other movements, will be able to generate countervailing power.

Past democratizations have sometimes generated elite efforts, some successful, to sidestep the new challenge to themselves. For example: one of the institutional bases of early modern slavery in the British Caribbean had been the considerable autonomy of planter-run local government. British island plantocracies tenaciously demanded their freedom from central dictate. In the wake of nineteenth-century slave emancipation, and further challenged by metropolitan notions of expanding suffrage rights, the planter elite of places like Montserrat and Dominica now shifted to supporting direct crown rule and the disempowerment of a local legislature in which nonwhites had a voice, ${ }^{48}$ On the edge of the twenty-first century, the unrivalled democratization of the states is now challenged by a new redeployment of power ${ }^{49}$ The actions of people in rural villages and urban workshops played a major role in the history of early modern states; the emerging social movements of the nineteenth century played a major role in the democratization of some of them. It remains to be seen whether the construction of the world order of the twenty-first century continues as a nearly exclusively elite project or whether social movements (or new forms of contestation to be invented) can inject a more democratic element into the emerging structures of global governance.
Lots of challenges, in short. Despite the wave-like pattern of ebb and flow of democratic history, the geographic extensiveness of the present diffusion of democratic forms should not mislead us, like Bryce at the end of World War I, ${ }^{50}$ to see the major challenge as one of further geographic range. Extending the current democratic institutions of some of the states to still other states embedded in the global marketplace will not be adequate to deal with the challenge of a what a more democratic world might be like Yet the strength of the core notion of a self-ruling people that has repeatedly, if intermittently, galvanized institutional change for two centuries remains. Democratic legitimations are now widespread and may energize new movements in many states. And more importantly, this may lead to pressures to democratize emerging structures of transnational power. And the challenges posed by globalization may be complemented by new possibilities as well. If, for example, I referred repeatedly to the political clout of labor, we may well ask if the movement of a great deal of manufacturing out of the traditional industrial heartlands might be the prelude to a new wave of labor activism in new places. On the historical record, indeed, the places where the new institutions of a renewed democracy will be pioneered - if anywhere-are likely not to be in the old centers where past success leads people to think the rest of the world need only copy them. For the democratic challenge for the twenty-first century, if democracy is not to become trivialized, will demand more than the extension of a known, completed, fixed model to new territories. If democracy is to have a meaningful future, it will have to be redefined and reinvented, as it always has been.

\section{NOTES}

Jean-Jacques Rousseau, Du Contrat social, Book III, chapter 15 (Paris: Aubier Montaigne, 1943), p. 340.

2. Frank O'Gorman, Voters, Patrons, and Parties: The Unreformed Electoral System of Hanoverian England 1734-1832 (Oxford: The Clarendon Press, 1989) and "Campaign Rituals and Ceremonies: The Social Meaning of Elections in England 1780-1860," Past and Present no. 135, 1992, pp.79-115.

. Morgan, Inventing the People, pp. 174-233; David Zaret, "Petitions and the 'Invention' of Public Opinion in the English Revolution," American Journal of Sociology 101, 1996, pp. 1497-1555.

4. George Rude, Wilkes and Liberty. A Social Study of 1763 to 1774 (Oxford, Clarendon Press, 1962). 
5. For many examples, see John Markoff, The Abolition of Feudalism. Peasants, Lords, and Legislators in the French Revolution (University Park, PA: The Pennsylvania State University Press, 1997), pp. 203-336.

6. A fine beginning: Wayne te Brake, Shaping History: Ordinary People in European Politics, 1500-1700 (Berkeley: University of California Press, 1998).

The very big claims that follow are best developed by Charles Tilly and Sidney Tarrow. See Charles Tilly, "Democracy Is a Lake" and "Parliamentarization of Popular Contention in Great Britain, 1758-1834", both in Charles Tilly, Roads from Past to Future (Lanham, MD: Rowman and Littlefield, 1997), pp.193-244, and Popular Contention in Great Britain, 1758-1834 (Cambridge, MA: Harvard University Press, 1995); Sidney Tarrow, "'The Very Excess of Democracy': State Building and Contentious Politics in America," pp. 20-38, in Anne N. Costain and Andrew S. McFarland, Social Movements and American Political Institutions (Lanham, MD: Rowman and Littlefield, 1998) and Power in Movement: Social Movements, Collective Action and Politics, 2nd ed., (New York: Cambridge University Press, 1998)

8. Robert R. Palmer, "Notes on the Use of the Word "Democracy', 1789-1799," Political Science Quarterly 68, 1953, pp. 203-226; Werner Conze and Reinhart Koselleck, eds., Geschichtiche Grundbegriffe. Historisches Lexikon zur politisch-sozialen Sprache in Deutschland (Stuttgart: Klett Verlag, 1972-1984), v. 1, pp. 821-899; Pierre Rosanvallon, "The History of the Word Democracy in France", Journal of Democracy 6, 1995, pp. 140-154; Horst Dippel, "Démocratie, Démocrates", in Rolf Reichardt and Eberhard Schmitt, eds., Handbuch politsch-sozialer Grundbegriffe in Frankreich 1680-1920 (Munich: Oldenbourg, 1986), v. 6, pp. 57-97; Jens A. Christophersen, The Meaning of "Democracy" as Used in European Ideologies from the French to the Russian Revolutions. An Historical Study of Political Language (Oslo: Universitetsforlaget, 1968); Robert W. Shoemaker, "Democracy' and 'Republic' as Understood in Late Eighteenth Century America," American Speech 41, 1966, pp. 83-95.

9. Consider the constitution issued by the restored French monarchy in 1814, announced in its royal preamble as in recognition "of the wishes of our subjects". See "Charte constitutionelle de 4 juin 1814," in Maurice Duverger, Constitutions et documents politiques (Paris: Presses Universitaires de France, 1960), p. 80

10. Samuel P. Huntington, The Third Wave: Democratization in the Late Twentieth Century (Norman, OK: University of Colorado Press, 1991); John Markoff, Waves of Democracy: Social Movements and Political Change (Thousand Oaks, CA: Pine Forge Press, 1996).

1. For discussion of the semiperipheral location of much democratic innovation, see John Markoff, "From Center to Periphery and Back Again: Reflections on the Geography of Democratic Innovation" in Michael Hanagan and Charles Tilly, eds., Extending Citizenship, Reconfiguring States (Lanham, MD: Rowman and Littlefield, 1999), pp. 229-246; and "Where and When Was Democracy Invented?", Comparative Studies in Society and History (forthcoming).

12. Ithiel de Sola Pool, Symbols of Democracy (Stanford, CA: Stanford University Press, 1952).

Globalization and the Future of Democracy

13. Roberto P. Korzeniewicz and Kimberley Awbrey, "Democratic Transitions and the Semiperiphery of the World-Economy," Sociological Forum 7, 1992, pp. 609-640.

14. Francis Fukuyama, "The End of History?", National Interest 16, 1989, pp. 3-18.

15. Huntington, Third Wave, pp. 13-26; Markoff, Waves of Democracy, pp. 71-99.

16. For various arguments about "globalization", see Robert Keohane and Helen Milner, eds., Internationalization and Domestic Politics (New York: Cambridge University Press, 1996); David Held, Democracy and the Global Order. From the Modern State to Cosmopolitan Government (Stanford: Stanford University Press, 1995); Martin Albrow, The Global Age: State and Society Beyond Modernity (Stanford: Stanford University Press, 1997); Arjun Appadurai, Modernity at Large: Cultural Dimensions of Globalization (Minneapolis, Minn.: University of Minnesota Press, 1996); Ulrich Beck, The Reinvention of Politics: Retbinking Modernity in the Global Social Order (Cambridge, Mass.: Polity Press, 1996); Ulf Hannerz, Transnational Connections: Culture, People, Places (London: Routledge, 1996); A. Douglas Kincaid and Alejandro Portes, Comparative National Development. Society and Economy in the New Global Order (Chapel Hill, NC: University of North Carolina Press, 1994); Roland Robertson, Globalization: Social Theory and Global Culture (London: Sage, 1992); Saskia Sassen, Cities in a World Economy (Thousand Oaks, CA: Pine Forge Press, 1994); Linda Weiss, "Globalization and the Myth of the Powerless State," New Left Review no. 225, 1997, pp. 3-27; Francis Fox Piven and Richard Cloward, The Breaking of the American Social Compact (New York: The New Press, 1997), pp. 3-14; Immanuel Wallerstein, Untbinking Social Science: The Limits of Nineteenth-Century Paradigms (Cambridge: Polity Press, 1991); Charles Tilly, "Globalization Threatens Labor's Rights," International Labor and Working-Class History no. 47, 1995, pp. 1-23 (with responses by Immanuel Wallerstein, Aristide R. Zolberg, E. J. Hobsbawm, and Lourdes Benería, pp. 24-55); Robert K. Schaeffer, Understanding Globalization: The Social Consequences of Political, Economic, and Environmental Change (Lanham, MD: Rowman and Littlefield, 1997); Leslie Sklair, Sociology of the Global System (Baltimore: The Johns Hopkins University Press, 1991); Robert Wade, "Globalization and its Limits: Reports of the Death of the National Economy are Greatly Exaggerated," in Suzanne Berger and Ronald Dore, eds., National Diversity and Global Capitalism (Ithaca, NY: Cornell University Press, 1996), pp. 60-88; Gladys Ganley, The Exploding Political Power of Personal Media (Norwood, NJ: Ablex, 1992); Manuel Castells, "European Cities, the Informational Society, and the Global Economy," New Left Review no. 204, 1994, pp. 18-32; Christopher Chase-Dunn, Yukio Kawana, and Denis Nikitin, "Globalization: A World-Systems Perspective", paper presented at the World Congress of Sociology, Montreal, 1998.

17. For an exemplary study, see Christopher Chase-Dunn, Yukio Kawano, and Benjamin Brewer, "Economic Globalization Since 1795: Structures and Cycles in the Modern World-System", paper presented at the meetings of the International Studies Association, Washington, DC, February, 1999.

18. These assertions rest, I hope not too precariously, on the accumulated data put forward in the works cited in the previous footnotes. What is needed is a demonstration a) that significant social interactions are happening across greater distances than in the past; b) that such an increase in recent decades is more than the current upswing of a 
recurrent cyclical pattern, but represents a trend; and c) that a and b hold for the globe as a whole rather than some limited part of it. No one has conclusively demonstrated any such thing, but I believe the evidence points in this direction. If this prove mistaken, much of what follows here would need to be rethought.

19. There is surely considerable variation from place to place in this regard. The U.S, for example has far more influence on the making of transnationally consequential decisions than many other places and is less at the mercy of market forces. One important symptom of the ideologically driven utility for some of claims that global competitiveness mandates dismantling first-world social safety nets is how much more prevalent such claims are in the U.S. than anywhere else in the first world, when the plausibility of such arguments is actually weaker there.

20. As I wrote the first draft of this essay in May 1998, the Indonesian government was wavering from one day to the next, between claiming to adhere to the demands of transnational finance and placating vast urban crowds of angry Indonesians who along with the friends and relatives of both the recently deposed and the newly elevated presidents - would be injured by such adherence.

21. I will not take up here the important question of the relationship of the U.S. to these institutions.

22. The extent of cross-border financing of political parties generally (and in the 1990 s in particular) seems to be scholarly terra incognita.

23. A valuable collection of essays may be found in Ezra N. Suleiman and John Waterbury, The Political Economy of Public Sector Reform and Privatization (Boulder, CO: Westview Press, 1990).

24. See the persuasive data assembled by Roberto P. Korzeniewicz and Timothy P. Moran, "World-Economic Trends in the Distribution of Income, 1965-1992," American Journal of Sociology 102, 1997, pp. 1000-1039; as well as Denny Braun, The Rich Get Richer. The Rise of Income Inequality in the United States and the World (Chicago: Nelson-Hall Publishers, 1997); Dani Rodrik, Has Globalization Gone Too Far? (Washington, D. C.: Institute for International Economics, 1997).

25. The extent to which confronting unemployment is a serious political strategy in, say, France (where it played an important role in the left's electoral victory in 1997), again suggests a range of variation that I ignore here.

26. For bibliography see Korzeniewicz and Moran, "World-Economic Trends".

27. T.H. Marshall, Citizenship and Social Class and Other Essays (Cambridge: Cambridge University Press, 1950); Bryan Turner, ed., Citizenship and Social Theory (London: Sage, 1993); Bart van Steenbergen, ed., The Condition of Citizenship (London: Sage, 1994); Charles Tilly, ed, Citizenship, Identity and Social History (Cambridge: Cambridge University Press, 1996); Michael Hanagan and Charles Tilly, eds., Recasting Citizenship (Lanham, MD: Rowman and Littlefield, forthcoming); Claus Offe, Modernity and the State. East, West (Cambridge, Mass: MIT Press, 1996); Frances Fox Piven and Richard Cloward, The Breaking of the American Social Compact (New York: The New Press, 1997).

28. For an especially compelling treatment of these issues in the new eastern Europe see Rogers Brubaker, Nationalism Reframed Nationbood and the National Question in the New
Globalization and the Future of Democracy

Europe (Cambridge: Cambridge University Press, 1996).

29. John Markoff and Verónica Montecinos, "The Ubiquitous Rise of Economists," Journal of Public Policy 13, 1993, pp. 37-68.

30. One of the strikingly common cultural characteristics of the recent democratizing transitions in far-flung parts of the world is the explosion of pornography, not nearly so evident previously in Warsaw, Madrid or Buenos Aires. This topic has yet to be adequately studied.

31. A serious issue in U.S.-French trade negotiation in the 1990s arose over French government subsidies for French films. The French claimed to be protecting French culture, which was threatened because the French movie-going public favored U.S. movies over French ones; the American government based its stand on notions of free competition in the marketplace. See New York Times December 8, 1993, p. A1; December 13, 1993, p. A1; December 14, 1993, p. A1; December 15, 1993, p. A1; January 6, 1994, p. D2.

32. On such grounds, for example, Diamond, Linz, and Lipset contend that ethnic conflicts are "the most difficult type of cleavage for a democracy to manage." See Larry Diamond, Juan J. Linz, and Seymour Martin Lipset, "Introduction", in Diamond, Linz and Lipset, eds., Politics in Developing Countries. Comparing Experiences with Democracy, 2nd ed. (Boulder, CO: Lynne Rienner, 1995), p. 42.

33. Important discussions of the issues treated here include: Tilly, "Globalization Threatens Labor's Rights;" Tarrow, Power in Movement, pp. 176-210, "Social Movements in Europe: Movement Society or Europeanization of Conflict?" European University Institute Working Paper RSC No. 94/8 and "Fishnets, Internets and Catnets: Globalization and Transnational Collective Action", in Michael Hanagan, Leslie Page Moch and Wayne te Brake, eds., Challenging Authority: The Historical Study of Contentious Politics (Minneapolis: University of Minnesota Press, 1998), pp. 228-244; Jackie Smith, C. Chatfield and Ron Pagnucco, eds. Transnational Social Movements in World Politics: Solidarity Beyond the State (Syracuse: Syracuse University Press, 1997); Jackie Smith, "Transnational Political Processes and the "Human Rights Movement', in Michael Dobkowski, Isidor Wallimann, and Christo Stojanov, Research in Social Movements, Conflicts and Change, vol. 18 (Greenwich, CN: JAI Press, 1995), pp. 185-219. Michael Hanagan, "Transnational Social Movements, Deterritorialized Migrants, and the State System: A Nineteenth-Century Case Study," in Marco Giugni, Doug McAdam and Charles Tilly, eds., How Movements Matter (Minneapolis: University of Minnesota Press, 1998); Alison Brysk, "Acting Globally: Indian Rights and International Politics in Latin America, in Donna Lee Van Cott, ed., Indigenous Peoples and Democracy in Latin America (New York: St. Martin's, 1994), pp. 29-51; Margaret E. Keck and Kathryn Sikkink, Activists Beyond Borders. Advocacy Networks in International Politics (Ithaca, NY: Cornell University Press, 1998).

34. The claims found below rest on data or analyses in the following: Sidney Tarrow, Power in Movement. Social Movements and Contentious Politics (Cambridge: Cambridge University Press, 1998), pp. 176-195 and "Building a Composite Polity: Popular Contention in the European Union", Cornell University Institute for European Studies Working Paper 98.3, 1998; Jackie Smith, Charles Chatfield and Ron 
Pagnucco, eds., Transnational Social Movements and Global Politics. Solidarity Beyond the State (Syracuse: Syracuse University Press, 1997); Margaret Keck and Katherine Sikkink, Activists Beyond Borders. Advocacy Networks in International Politics (Ithaca, NY; Cornell University Press, 1998); John Markoff, Waves of Democracy: Social Movements and Political Change (Thousand Oaks, CA: Pine Forge Press, 1996), pp. 27-31.

35. For some quantitative data from Europe, see Sidney Tarrow, "Building a Composite Polity: Popular Contention in the European Union", Cornell University Institute for European Studies Working Paper, 98.3, 1998.

36. Keck and Sikkink, Activists Beyond Borders, p. 11. See also Tarrow, Power in Movement, pp. 184-195.

37. Jackie Smith, "Characteristics of the Modern Transnational Social Movement Sector" in Smith, Chatfield and Pagnucco, Transnational Social Movements, p. 47.

38. Activists Beyond Borders examines the sources of variation in the effectiveness of transnational advocacy networks.

39. Susan George and Fabrizio Sabelli, Faith and Credit: The World Bank's Secular Empire (Boulder, CO: Westview Press, 1994).

40. George and Sabelli, Faith and Credit, p. 214. The extremely complex formal rules for IMF decision-making have been described in the literature (Frederick K. Lister, Decision-Making Strategies for International Organization: The IMF Model, Vol. 20, Book 4. Monograph Series in World Affairs, Graduate School of International Affairs, University of Denver, 1984). What seems to have escaped scrutiny, however, is the political process of reaching actual decisions by the Bank and the Fund.

${ }^{41}$. Democracy in America (New York: Knopf, 1945), v. 1, pp. 57, 197, 199. If voting rights were universal in the U.S. Tocqueville visited in 1831, it was but a short step to urge: "At the present day the principle of the sovereignty of the people has acquired in the United States all the practical development that the imagination can conceive" ( $v$. 1, p. 57).

42. Yasemin Soysal, Limits of Citizenship: Migrants and Postnational Membership in Europe (Chicago: University of Chicago Press, 1994).

43. For example, Immanuel Wallerstein, "Response: Declining State, Declining Rights?," International Labor and Working-Class History 47, 1995, pp. 24-27.

44. Movements involving working-class people in core countries on behalf of the rights of people in colonies, like the British antislavery movement, demand more systematic attention from students of social movements than they have received. For example, see Seymour Drescher, Capitalism and Antislavery. British Mobilization in Comparative Perspective (New York: Oxford University Press, 1987).

45. For a superb case study of how democracy and colonial rule could be fused, see Alice Conklin, "Colonialism and Human Rights, a Contradiction in Terms? The Case of France and West Africa, 1895-1914", American Historical Review 103, 1998, pp. $419-442$.

46. The touchstone for subsequent discussion has been Seymour Martin Lipset's essay of 1959 that now appears as the chapter on "Economic Development and Democracy" in his Political Man. The Social Bases of Politics, expanded edition (Baltimore, MD: The Johns Hopkins University Press, 1981), pp. 27-63.

47. Beverly Silver, "Turning Points in Workers' Militancy in the World Automobile Industry, 1930s-1990s," in Randy Hodson, ed., Research in the Sociology of Work, 1* 6 (Greenwich, CT: JAI Press, 1998), pp. 41-69 and Workers of the World in the Twentieth Century (forthcoming).

48. Arthur L. Stinchcombe, Sugar Island Slavery in the Age of Enlightenment. The Political Economy of the Caribbean World (Princeton: Princeton University Press, 1995), pp. 276 277.

49. With specific reference to the emergence of the European Union, see John Markoff, "Our Common European Home - But Who Owns the House?", in Dennis Smith, ed, Whose Europe? (London: Basil Blackwell, forthcoming).

50. James Bryce, Modern Democracies (New York: Macmillan (1921), pp. 4-5. 